Article

\title{
Optimum Design of PID Controlled Active Tuned Mass Damper via Modified Harmony Search
}

\author{
Aylin Ece Kayabekir ${ }^{1, *}$, Gebrail Bekdass ${ }^{1}$, Sinan Melih Nigdeli ${ }^{1}$ and Zong Woo Geem ${ }^{2, *}$ (]) \\ 1 Department of Civil Engineering, Istanbul University - Cerrahpaşa, 34310 Istanbul, Turkey; \\ bekdas@istanbul.edu.tr (G.B.); melihnig@istanbul.edu.tr (S.M.N.) \\ 2 College of IT Convergence, Gachon University, Seongnam 13120, Korea \\ * Correspondence: aylinecekayabekir@ogr.iu.edu.tr (A.E.K.); geem@gachon.ac.kr (Z.W.G.); \\ Tel.: +82-31-750-5586 (Z.W.G.)
}

Received: 2 April 2020; Accepted: 23 April 2020; Published: 24 April 2020

\begin{abstract}
In this study, the music-inspired Harmony Search (HS) algorithm is modified for the optimization of active tuned mass dampers (ATMDs). The modification of HS includes the consideration of the best solution with a defined probability and updating of algorithm parameters such as harmony memory, considering rate and pitch adjusting rate. The design variables include all the mechanical properties of ATMD, such as the mass, stiffness and damping coefficient, and the active controller parameters of the proposed proportional-integral-derivative (PID) type controllers. In the optimization process, the analysis of an ATMD implemented structure is done using the generated Matlab Simulink block diagram. The PID controllers were optimized for velocity feedback control, and the objective of the optimization is the minimization of the top story displacement by using the limitation of the stroke capacity of ATMD. The optimum results are presented for different cases of the stroke capacity limit of ATMD. According to the results, the method is effective in reducing the maximum displacement of the structure by $53.71 \%$, while a passive TMD can only reduce it by $31.22 \%$.
\end{abstract}

Keywords: active tuned mass dampers; harmony search; PID; structural control; optimization

\section{Introduction}

Structural responses to earthquakes, winds, traffic, and other dynamic forces can endanger structural safety and disrupt comfort. Consequently, research into reducing the structural response and vibrations under the action of dynamic forces has increased in recent years.

The control systems developed in these studies consume the energy entering the structure by providing additional damping. Such systems can be installed during construction or added to existing structures.

Control systems are generally divided into active and passive types, but also have other classifications depending on the design and equipment used. Tuned mass damper (TMDs) are passive control systems, which are implemented in several famous structures like Taipei 101 in Taipei (Figure 2a) and seismic retrofitted LAX Theme Building in Los Angeles [1]. In addition to these systems, it is possible to treat semi-active and hybrid control systems as a separate category.

Active tuned mass dampers (ATMDs), a type of active system, can be defined as a system derived by adding an active control mechanism (sensor, controller, and actuator) to the TMD system to increase its applicability at variable frequencies (Figure 1). As seen in Figure 1, the response of the top story (top story velocity in the numerical example) is used as the feedback of the controller to generate the time-varying control force linear dynamic actuators. In applications, different and multiple feedbacks for the sensors and different types of actuators can also be used. There are several practical examples of ATMDs, such as Shinjuku Park Tower (227 m) in Tokyo, Japan, Incheon International Airport Control 
Tower (100.4 m) in Incheon, Korea, Air Traffic Control Tower (57 m) in Edinburgh, UK, and Shanghai World Financial Center (492 m) in Shanghai, China (Figure 2b) [2].

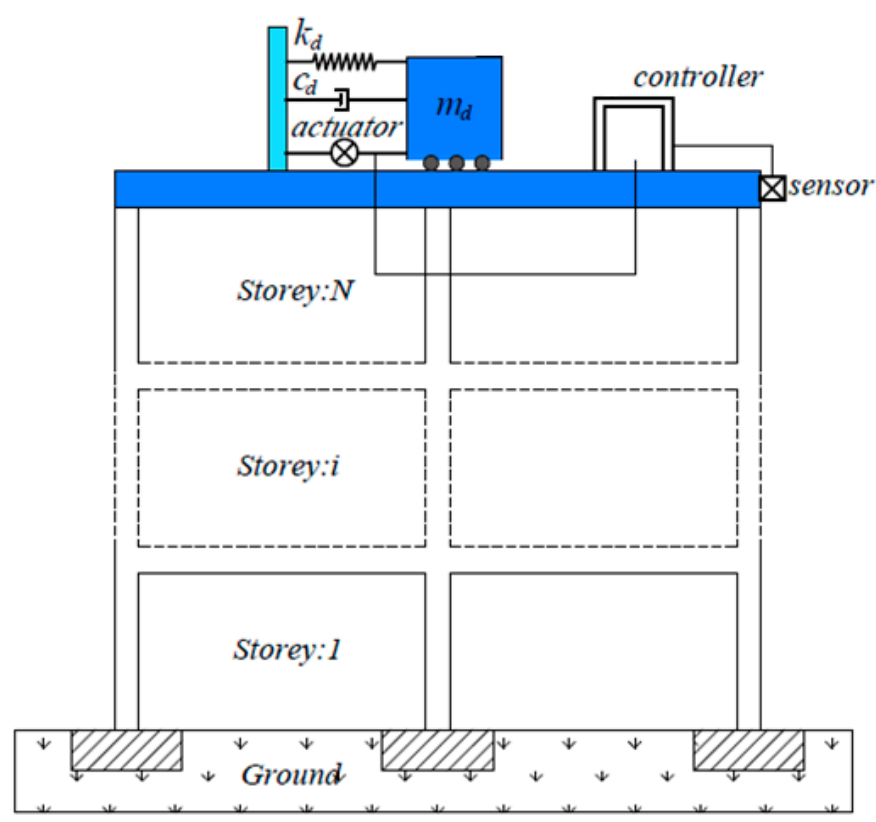

Figure 1. General component of structure with an active tuned mass dampers (ATMD) system.

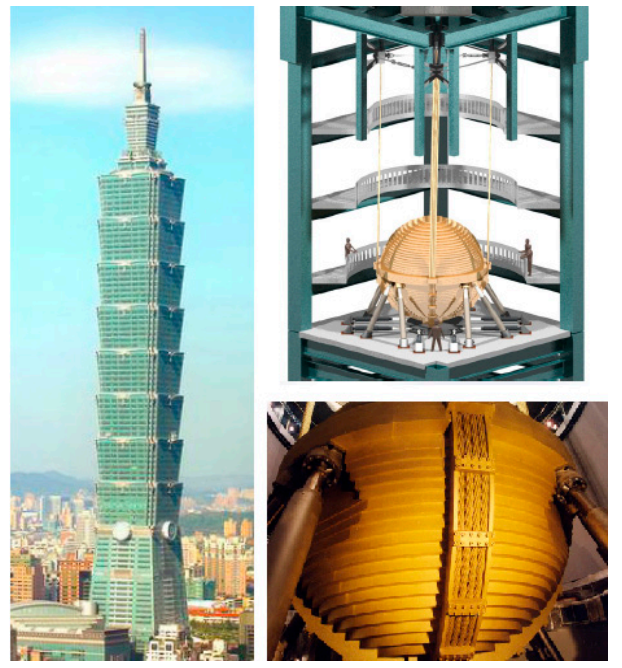

(a)

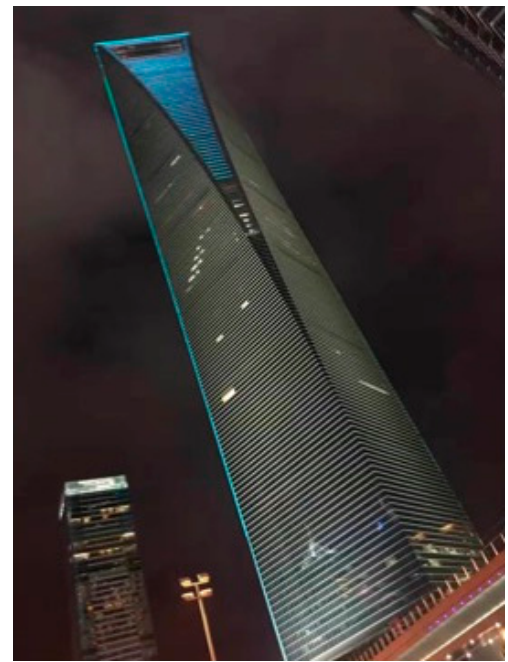

(b)

Figure 2. (a) Taipei 101 with a sphere-shaped tuned mass damper [3] (b) Shanghai World Financial Center in Shanghai, China.

In this section, ATMD system studies are presented chronologically.

Ankireddi and Yang designed an ATMD for the vibration control of tall buildings exposed to wind loads. In that study, wind loads were modeled with white noise and a full feedback (displacement, velocity, and acceleration) control algorithm was used for the control of the ATMD system [4]. Mackriell et al. positioned ATMDs atop two tall structures to provide first-mode vibration control for wind effects, and found that the control algorithm using acceleration feedback was successful in reducing structural responses [5]. Yan et al. used a norm control technique using root mean square responses $\left(\mathrm{H}_{\mathrm{rms}}\right)$ in an optimum ATMD design and tested the sensitivity of numerical expressions derived by Ankireddi and Yang [4] for optimum ATMD design under more complex wind effects. Tests have determined that the method proposed by Ankireddi and Yang [4] was sufficient for finding the optimum parameters under 
along-wind excitations, whereas for under-wind excitations, it was revealed that the optimum frequency ratio could not be achieved, requiring a modification to the frequency ratio [6]. Qu et al. suggested the use of a dynamic condensation method, which is an iterative method. It is necessary to use a low-order control on the ground, but placing a sensor on each floor is not a practical solution [7]. Samali and Al-Dawod compared the performances of fuzzy logic controller (FLC) and linear quadratic regulator (LQR) control algorithms using five-story structure models to ATMD [8]. Similarly, Samali et al. applied an ATMD system with an FLC control algorithm to a 76-story reinforced-concrete office tower with a height of $306 \mathrm{~m}$ in Melbourne, Australia, and the performance of the control system under the wind load was compared with an ATMD system with a linear quadratic Gaussian control algorithm [9]. Li proposed a lever-type ATMD/LT-ATMD to obtain a high-performance active control system in structures under a harmonic influence. In that study, the performance of the system was calculated by using the values of dynamic magnification factor [10]. Han and Li used multiple ATMDs (AMTMDs), which consist of ATMDs with the same damping and stiffness coefficients and different mass and control forces, in order to reduce the oscillations occurring due to ground vibrations [11]. Pourzeynali et al. suggested using fuzzy logic control (FLC) and genetic algorithm (GA), which are metaheuristic algorithms, for the control of high-rise structures against earthquake effects with ATMD [12]. Li and Xiong suggested using an AMTMD to reduce the horizontal and torsional responses of asymmetric structure models simplified to two degrees of freedom (2DOF) [13]. Guclu and Yazici designed an ATMD system that uses Proportional-Derivative (PD) and FLC control algorithms to limit structural vibrations [14]. PD controllers have only two actions. These actions, which are proportional action and derivative action, are defined by the parameters called proportional gain and derivative time, respectively. In PD, the error signal and the derivative of the error signal are used in the production of the control signal. By the addition of integral action defined with integral time to use the integral of the error signal, proportional-integral-derivative (PID) controllers are generated. In another study, Guclu and Yazici used a fuzzy proportional-integral-derivative (PID) controller with an ATMD system structure to limit the structural vibrations caused by the earthquake effect [15]. Guclu and Yazici also proposed the self-adjusting FLC for the active control of ATMD structures [16]. Li et al. suggested using the ATMD system to reduce the linear and torsional responses that may occur in asymmetric structures in an earthquake. In the study, optimum ATMD parameters are determined by using the minimum linear and torsional displacement minimization criteria and the gradient search method [17]. $\mathrm{Li}, \mathrm{C}$. analyzed asymmetric structures with an AMTMD control system, in which the soil structure interaction (SSI) was taken into account. In that study, the optimum parameter criterion was defined as the minimization of the mean square root values of the horizontal and torsional displacements [18]. Fitzgerald and Basu have developed an active control method to reduce out-of-plane vibrations in the engine compartment of wind turbines. In that study, in which soil-structure and wing-tower interactions are also taken into consideration, an ATMD system with an LQR controller was used [19]. Amini et al. used particle swarm optimization (PSO) and linear quadratic regulator (LQR) to find the optimum active control force in ATMD-controlled structures [20]. You et al. investigated an ATMD system with a linear quadratic Gaussian (LQG) controller in order to reduce wind-induced responses in high-rise buildings [21]. In the study, ATMD parameters (tuning frequency and damping ratio) were found by a numerical optimization method developed by Ayorinde and Warburton [22]. Shariatmadar et al. suggested using the interval type-2 FLC algorithm for the active control of structural systems modeled as single degree of freedom with ATMD systems [23]. Two identical ATMDs were used to reduce the wind-induced vibration of the Shanghai World Financial Center Tower in China [24]. Shariatmadar and Meshkat Razavi suggested using fuzzy logic control (FLC) and particle swarm optimization (PSO) to reduce vibrations in a structure experiencing an earthquake [25].Soleymani and Khodadadi suggested using a "multi-objective adaptive genetic-fuzzy" controller to control tall structures exposed to high earthquake activity and repeated wind load by ATMD [26]. Li and Cao suggested using a hybrid active tuned mass damper (HATMD) to reduce vibrations caused by ground acceleration in the buildings. The HATMD system has a unique feature, adopting both the negative 
normalized acceleration feedback gain factors and positive normalized acceleration feedback gain factors in the generation of the control forces [27]. In addition to the HATMD system proposed in their study, Cao and Li developed one more by adding a dashpot connection between the structure and ATMD masses (EHATMD) [28]. Heidari et al. proposed a system that combines PID control with LQR controllers to develop the traditional LQR control algorithm [29].

The implemented control systems need a perfect tuning according to the behavior of the structure and seismic excitations. In this manner, optimization is a must for structural control. In this study, the music-inspired harmony search algorithm is modified for the optimum tuning problem of ATMDs. The methodology, using the novel approach, uses the time-history responses of set of ground acceleration records to verify the robustness of the system under different excitations. The proposed metaheuristic approach is effective to find the optimum values of design variables, covering both mechanical and control algorithm parameters. The proposed ATMD system uses PID controllers, which have three gains to optimize in addition to the physical parameters of ATMD such as mass, stiffness and damping coefficients.

\section{The Analysis of Structures with ATMD}

To investigate the structural responses to seismic excitation, a dynamic analysis of the structure must be performed. To conduct a dynamic analysis, the structure models' equations of motion must be solved. This study considers a shear building model with an ATMD positioned on the top story (Figure 3). The analysis of the structure models was performed using Matlab with Simulink [30]. This process is repeated for every iteration of the optimization process and for different earthquake excitations to find robust solutions that are not sensitive to the change in excitation. The generated Matlab Simulink diagrams of the equations of motion of the structure use a 4th-order Rung-Kutta method for the time history responses.

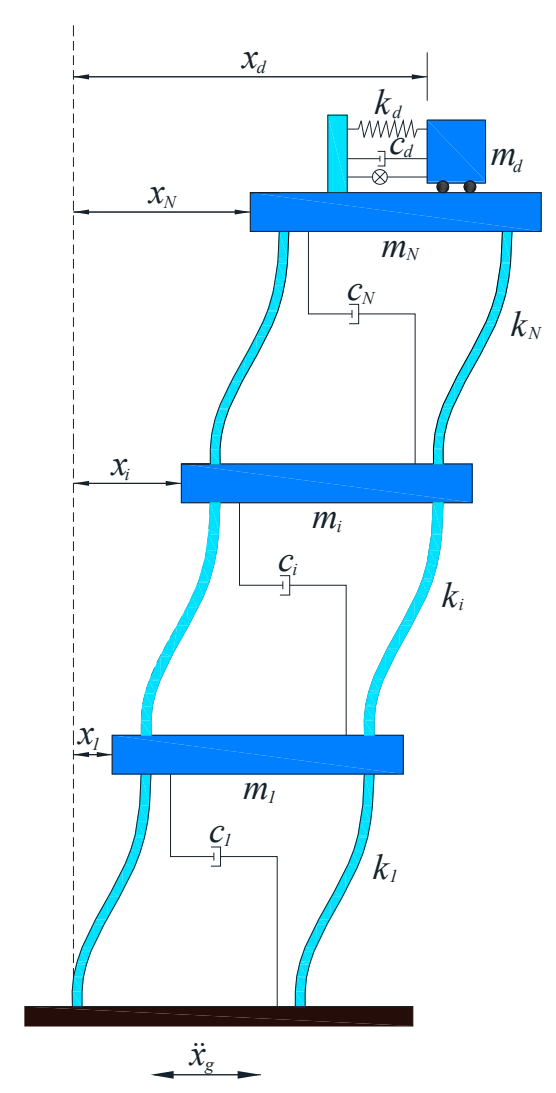

Figure 3. A structural model with ATMD on the top. 
As shown in Figure 3, the properties of the story are denoted by $m_{i}, k_{i}$, and $c_{i}$ for the mass, stiffness, and damping coefficient of the ith story of the structure, respectively. The properties of the ATMD are shown as $m_{d}, k_{d}$, and $c_{d}$ for the mass, stiffness, and damping, respectively. The ATMD is attached to an actuator to provide a control force. This force is applied to the ATMD and the top story $\left(\mathrm{N}^{\text {th }}\right)$ as a reaction.

As classically known, the equation of structure is written as Equation (1).

$$
M \ddot{x}(t)+C \dot{x}(t)+K x(t)=-M\{1\} \ddot{x}_{g}(t)+F(t)
$$

$\mathrm{M}, \mathrm{K}$, and $\mathrm{C}$ are the mass, stiffness, and damping matrixes, respectively, as follows.

$$
\begin{aligned}
& M=\operatorname{diag}\left[m_{1} m_{2} \ldots m_{N} m_{d}\right]
\end{aligned}
$$

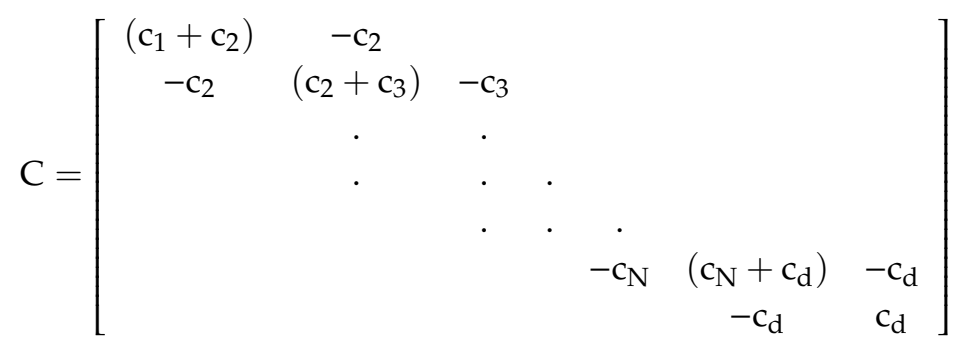

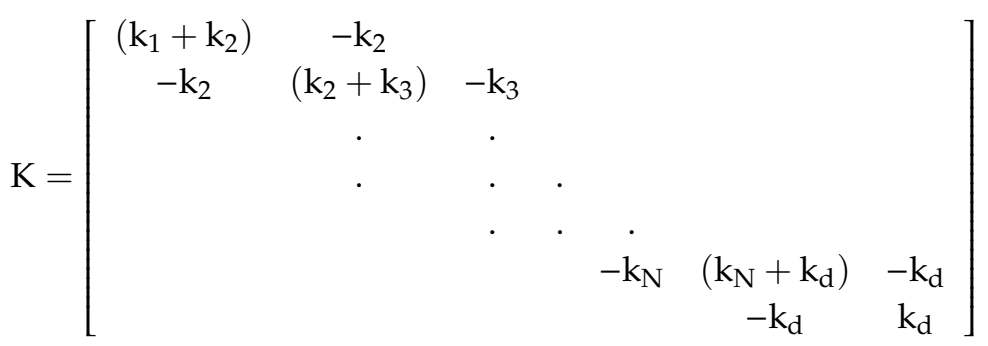

These three matrices are multiplied with the response and its derivative respect to time, as seen in Equation (1). The response of the structure $x(t)$ is the vector of story and ATMD displacements, as shown as Equation (5). The control force vector $(F(t))$ is as seen Equation (6), and Fu represents the control force produced by the actuator.

$$
\begin{gathered}
x(t)=\left\{\begin{array}{c}
x_{1} \\
x_{2} \\
\vdots \\
x_{N} \\
x_{d}
\end{array}\right\} \\
F(t)=\left\{\begin{array}{c}
0 \\
0 \\
\vdots \\
F_{u} \\
-F_{u}
\end{array}\right\}
\end{gathered}
$$

As seen in Equation (7), the control force is produced by the multiplication of trust constant $\left(\mathrm{K}_{\mathrm{f}}\right)$ and current of armature coil ( $\left.\mathrm{i}_{\text {ATMD }}\right)$.

$$
\mathrm{F}_{\mathrm{u}}=\mathrm{k}_{\mathrm{f}} \mathrm{i}_{\text {ATMD }}
$$


The current of armature coil can be found according to Equation (8), where $R, K_{e}$ and $u$ represent the resistance value, the induced voltage constant of armature coil and the control signal produced according to control algorithm, respectively. The velocity values of ATMD $\left(\dot{x}_{\mathrm{d}}\right)$ and top story $\left(\dot{x}_{\mathrm{N}}\right)$ are also used in Equation (8).

$$
\operatorname{Ri}_{\text {ATMD }}+\mathrm{k}_{\mathrm{e}}\left(\dot{\mathrm{x}}_{\mathrm{d}}-\dot{\mathrm{x}}_{\mathrm{N}}\right)=\mathrm{u}
$$

In the present study, the control signal is found according to PID controllers. The formulation of PID controllers is shown as Equation (9).

$$
u=k_{p}\left[e(t)+T_{d} \frac{d e(t)}{d t}+\frac{1}{T_{i}} \int e(t) d t\right]
$$

As seen in Equation (9), the PID controller parameters are the proportional gain $\left(K_{p}\right)$, derivative time $\left(T_{d}\right)$ and integral time $\left(T_{i}\right)$. These linear controllers transform the error signal $e(t)$ to control signal (u). The error signal is the chosen response of the system, which aims to reduce with control. Since the velocity of the structure directly affects the kinetic energy of the structure excited by the earthquake and the ATMD was positioned on the top story, where the responses are generally maximum, the error signal was chosen as the top story velocity of the structure $\left(\dot{x}_{N}\right)$ in the study. Here, velocity is measured via sensor and velocity feedback control is performed.

In the optimum tuning of PID-controlled ATMD, six different design variables are considered to reduce the value of the objective function, which is taken as the displacement of the top story. The maximum absolute value solution is considered for extremum solution, and the maximum response under different excitations is considered in the optimization process. The objective function is formulized as Equation (10). In this study, the minimization of maximum top story displacement is chosen as the optimization objective. Also, other critical responses can be considered in structural control systems. The different optimum design strategies were reviewed by De Domenico et al. [31]. The performance criteria used as objectives may be related to energy perspective results [32], inter-story drifts, accelerations [33] or multi-objectives of several of them [34].

$$
\mathrm{f}(\mathrm{x})=\max \left(\left|\mathrm{x}_{\mathrm{N}}\right|\right)
$$

The objective function is constrained with a function $\left(\mathrm{g}_{1}\right)$ to consider the limitation of the movement of ATMD. It is formulated as Equation (11).

$$
\mathrm{g}_{1}=\frac{\max \left(\left|\mathrm{x}_{\mathrm{d}}-\mathrm{x}_{\mathrm{N}}\right|\right)_{\text {with ATMD }}}{\max \left(\left|\mathrm{x}_{\mathrm{N}}\right|\right)_{\text {without ATMD }}}<\text { st_max }
$$

st_max is a user-defined value for the stroke limitation of ATMD. In the constraint, a normalization is performed with respect to the uncontrolled structure.

The design variables are the physical parameters of mass damper and the gains of the controller. The ranges of physical parameters can be defined according to application. The mass of ATMD must be limited with respect to the axial force capacity of the structure, and it is generally defined with a ratio respect to the total mass of the structure. The stiffness of ATMD $\left(k_{d}\right)$ is tuned by optimizing the period of ATMD ( $\left.T_{a t m d}\right)$, as formulated as Equation (12). The value of $T_{a t m d}$ must be close to the critical period of the structure. A range around that value can be chosen.

$$
\mathrm{T}_{\mathrm{atmd}}=2 \pi \sqrt{\frac{\mathrm{m}_{\mathrm{d}}}{\mathrm{k}_{\mathrm{d}}}}
$$


The damping of ATMD is generally defined with damping ratio $\left(\xi_{\mathrm{d}}\right)$, given as Equation (13). For that reason, $\xi_{d}$ is taken as a design variable.

$$
\xi_{\mathrm{d}}=\frac{c_{\mathrm{d}}}{2 \mathrm{~m}_{\mathrm{d}} \sqrt{\frac{\mathrm{k}_{\mathrm{d}}}{\mathrm{m}_{\mathrm{d}}}}} x 100
$$

The PID controller gains can be optimum in any value. This situation may increase optimization process time and some values will have a negative effect on structure. In some combinations of controller gains, a stability problem that resulted in a resonance state of the structure can be seen. The numerical integration methods may give non-defined solutions, and the optimization process may be interrupted. For that reason, trial and error may be used for finding a range, but the optimum value may be out of the range that is found with trial and error. To circumvent these pitfalls, a Matlab Simulink block diagram comparison check is performed on the displacement of a ATMD-controlled structure for each time-lag; if the value exceeds the value of the maximum displacement of the structure without control, the simulation is ended. In addition, to prevent the stability problem, it is saved from the computation time of the optimization process. The optimization iterations continue by generating new values.

\section{The Modification of Harmony Search Algorithm}

Like all branches of art, the work in the music branch appears after a long process. In this process, various factors such as age and the place in which artist lives, social relationship and structure play an active role during creating the artwork. During this process, by trying various notes and tones of these notes, musician reveals the preliminary of the artwork. Then, musicians try to find the best combination to gain the audience's admiration. The artist creates the final version of the work by changing notes of the preliminary created artwork according to critic and listener views.

The HS algorithm, a memory-based random search method, is inspired by the process of a musician searching for the best combination of notes (i.e., a harmony) when creating a work [35].

In the HS algorithm, application of this process to the optimization problem can be summarized in five steps. In the first step, the design constants of the problem, the upper and lower limits of the design variables and the values of the algorithm-specific parameters and the maximum iteration number are defined. The HS algorithm uses three parameters, namely the harmony memory size (HMS), the harmony memory consideration rate (HMCR), and the pitch adjustment rate (PAR).

In the second step, a vector named the harmony vector is created by generating a random value $(\operatorname{rnd}(0,1))$ between upper $\left(X_{i, \max }\right)$ and lower limits $\left(X_{i, m i n}\right)$ defined for each design variable $\left(X_{i}\right)$ (Equation (14)). By using these design variables and problem constants, the equation of motion is solved and the objective function for this solution is obtained. The value of this objective function is also stored in the harmony vector. This process is repeated as much as the size of the harmony memory permits, and each harmony vector is stored in a matrix called initial solution matrix.

$$
X_{i}=X_{i, \min }+\operatorname{rnd}(0,1) \cdot\left(X_{i, \max }-X_{i, \min }\right)
$$

The third step includes the iteration process. In this step, the new harmony vector is created. According to the algorithm rules, the new vector can be created in two ways. The first is to generate the design variables randomly between the defined upper and lower limits, as described in the second step. 
In the second option, a new vector is generated using a vector selected ( $\mathrm{Xi}$,old) from the solution matrix (Equation (15)). During this creation process, new values ( $\mathrm{Xi}, \mathrm{new}$ ) are obtained randomly by multiplying the difference of design variable limits and the Pitch Adjusting Rate (PAR). In this study, PAR is used similar to fret width.

$$
X_{i, \text { new }}=X_{i, \text { old }}+\operatorname{rnd}(0,1) \cdot P A R \cdot\left(X_{i, \max }-X_{i, \min }\right)
$$

Depending on the value of the harmony memory consideration rate (HMCR), which of these two options to use as the new vector is decided. Accordingly, a random value is generated, and if this value is less than the HMCR, the first option (Equation (14)) is selected; otherwise, the second option (Equation (15)) is selected.

As the modification of HS for the optimal tuning of ATMD, the selected existing solution ( $\mathrm{Xi}$, old) is defined in two ways. In the first way, it is chosen as the best existing solution. The probability of using the best solution is defined with a parameter called the best solution considering rate (BSCR). Like HMCR, it is also compared with a random number for the decision. For the other cases, $X_{i, \text { old }}$ is randomly chosen from one of the solutions.

The second modification involved using variable HMCR and PAR values. In this study, HMCR and PAR parameters, which are constant in the original HS algorithm, have been changed depending on the iterations given in Equations (16) and (17). By this modification, PAR and HMCR parameters get smaller by the iterations. In that case, the optimum results are searched within a smaller range around an existing solution by the decrease in PAR. By the reduction in HMCR, the second option will be more possibile. The second option is a local search phase and the convergence to the optimum best solution increases. If small constant PAR and HMCR values are used without modification, the optimization process may trap to a local optimum result, since the process generally urge a local search with a small range at the start. Small parameters may be an advantage after the optimization process finds a good solution, close to the global optimum.

$$
\begin{gathered}
\mathrm{PAR}=\operatorname{PAR}_{\text {in }}\left(1-\frac{\mathrm{IN}}{\mathrm{MI}}\right) \\
\mathrm{HMCR}=\mathrm{HMCR}_{\text {in }}\left(1-\frac{\mathrm{IN}}{\mathrm{MI}}\right)
\end{gathered}
$$

MI and IN are the maximum iteration number and current iteration number, respectively. The initial values of algorithm parameters at the start of the optimization process are shown as $P_{\text {An }}$ and $\mathrm{HMCR}_{\text {in }}$.

In the next step, the new vector is compared with the vectors stored in the solution matrix. If the new vector is better than the existing vector in the matrix, the existing vector is replaced by the new one, otherwise the solution matrix persists.

Comparison is done against the value of the objective function, and the minimum value is chosen as a better solution. The design constraints are also compared. If there are violations of the design constraints, the amount of violations is checked, and the solution with the minimum number of violations is chosen as the better solution.

In the last step, the stopping criterion is checked. The iterative process continues until the stopping criterion is satisfied. The stopping criterion, which can be defined in different ways, has been determined as the maximum number of iterations in this study. The optimization process of ATMD is summarized in the flowchart given as Figure 4. 


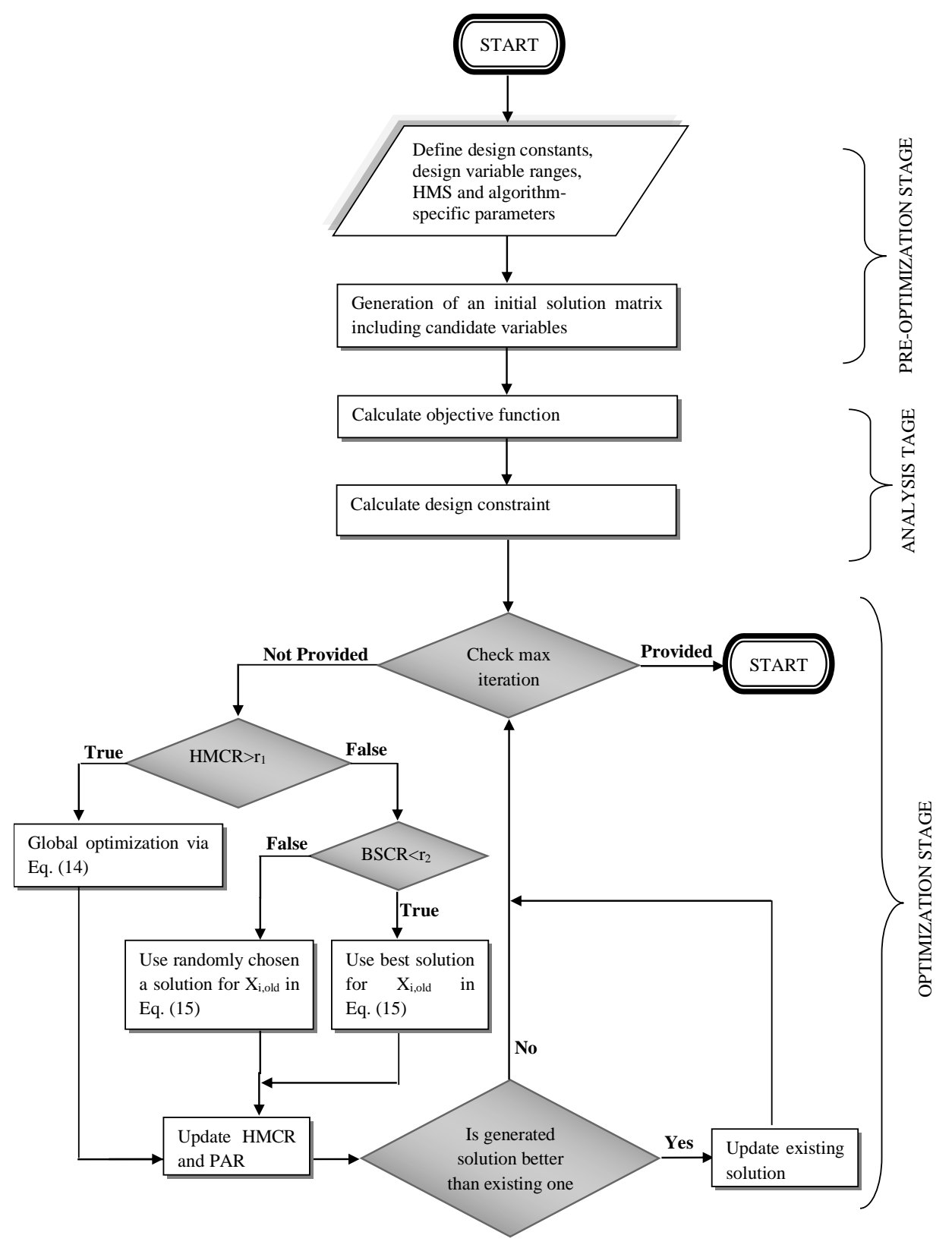

Figure 4. The flowchart of the optimization process.

\section{Numerical Examples}

A ten-story shear building [36] was investigated for an optimum ATMD at the top. The structure has the same properties for each floor. The design constants (structural properties), the ranges of design variables, and the algorithm parameters are listed with values in Table 1 . In addition, constant ATMD parameters are included in Table 1 [14].

The mass of TMD was searched in a range with a minimum $1 \%$ and maximum $5 \%$ of the total mass of the structure. The range of $\mathrm{T}_{\text {atmd }}$ is defined as 0.5 and 1.5 times the critical period of the uncontrolled structure. As seen from the ranges of the PID parameter, any specific range must not be found before the optimization due to modification done in Matlab Simulink, as explained in Section 2. The optimization process is done for three different st_max values such as 2, 3 and 4 . 
During the optimization process, 22 earthquake records were used. These records have 44 excitations (two in the longitudinal direction for each record), and these records are grouped as far-field ground motion records in FEMA P-695: Quantification of Building Seismic Performance Factors [37]. These records were also considered in various optimum structural control methodologies [38-41]. The information of excitations is listed in Table 2.

Table 1. The numerical data for structure case.

\begin{tabular}{|c|c|c|}
\hline Definition & Value & Unit \\
\hline $\mathrm{m}_{\mathrm{i}}$ & 360 & tons \\
\hline $\mathrm{k}_{\mathrm{i}}$ & 650 & $\mathrm{MN} / \mathrm{m}$ \\
\hline$c_{i}$ & 6.2 & $\mathrm{MNs} / \mathrm{m}$ \\
\hline $\mathrm{m}_{\mathrm{d}}$ & $36-180$ & tons \\
\hline $\mathrm{T}_{\mathrm{atmd}}$ & $0.495-1.484$ & $\mathrm{~s}$ \\
\hline$\xi_{\mathrm{d}}$ & $1-50$ & $\%$ \\
\hline $\mathrm{K}_{\mathrm{p}}$ & $(-10,000)-(10,000)$ & $\mathrm{Ns} / \mathrm{m}$ \\
\hline $\mathrm{T}_{\mathrm{d}}^{\mathrm{r}}$ & $(-10,000)-(10,000)$ & $\mathrm{s}$ \\
\hline $\mathrm{T}_{\mathrm{i}}$ & $(-10,000)-(10,000)$ & $\mathrm{s}$ \\
\hline st_max & $2-3-4$ & - \\
\hline HMS & 10 & - \\
\hline $\mathrm{HMCR}_{\text {in }}$ & 0.5 & - \\
\hline $\mathrm{PAR}_{\text {in }}$ & 0.05 & - \\
\hline BSCR & 0.3 & - \\
\hline MI & 5000 & - \\
\hline $\mathrm{R}$ & 4.2 & $\Omega$ \\
\hline $\mathrm{K}_{\mathrm{f}}$ & 2 & N/A \\
\hline $\mathrm{K}_{\mathrm{e}}$ & 2 & $\mathrm{~V}$ \\
\hline
\end{tabular}

Table 2. FEMA P-695 far-field ground motion records [33].

\begin{tabular}{ccccc}
\hline $\begin{array}{c}\text { Earthquake } \\
\text { Number }\end{array}$ & Date & Name & Component 1 & Component 2 \\
\hline 1 & 1994 & Northridge & NORTHR/MUL009 & NORTHR/MUL279 \\
2 & 1994 & Northridge & NORTHR/LOS000 & NORTHR/LOS270 \\
3 & 1999 & Duzce, Turkey & DUZCE/BOL000 & DUZCE/BOL090 \\
4 & 1999 & Hector Mine & HECTOR/HEC000 & HECTOR/HEC090 \\
5 & 1979 & Imperial Valley & IMPVALL/H-DLT262 & IMPVALL/H-DLT352 \\
6 & 1979 & Imperial Valley & IMPVALL/H-E11140 & IMPVALL/H-E11230 \\
7 & 1995 & Kobe, Japan & KOBE/NIS000 & KOBE/NIS090 \\
8 & 1995 & Kobe, Japan & KOBE/SHI000 & KOBE/SHI090 \\
9 & 1999 & Kocaeli, Turkey & KOCAELI/DZC180 & KOCAELI/DZC270 \\
10 & 1999 & Kocaeli, Turkey & KOCAELI/ARC000 & KOCAELI/ARC090 \\
11 & 1992 & Landers & LANDERS/YER270 & LANDERS/YER360 \\
12 & 1992 & Landers & LANDERS/CLW-LN & LANDERS/CLW-TR \\
13 & 1989 & Loma Prieta & LOMAP/CAP000 & LOMAP/CAP090 \\
14 & 1989 & Loma Prieta & LOMAP/G03000 & LOMAP/G03090 \\
15 & 1990 & Manjil, Iran & MANJIL/ABBAR-L & MANJIL/ABBAR-T \\
16 & 1987 & Superstition Hills & SUPERST/B-ICC000 & SUPERST/B-ICC090 \\
17 & 1987 & Superstition Hills & SUPERST/B-POE270 & SUPERST/B-POE360 \\
18 & 1992 & Cape Mendocino & CAPEMEND/RIO270 & CAPEMEND/RIO360 \\
19 & 1999 & Chi-Chi, Taiwan & CHICHI/CHY101-E & CHICHI/CHY101-N \\
20 & 1999 & Chi-Chi, Taiwan & CHICHI/TCU045-E & CHICHI/TCU045-N \\
21 & 1971 & San Fernando & SFERN/PEL090 & SFERN/PEL180 \\
22 & 1976 & Friuli, Italy & FRIULI/A-TMZ000 & FRIULI/A-TMZ270 \\
\hline
\end{tabular}


The optimum values of design variables, objective function and design constraints are given as Table 3. In Table 3, the optimum results of passive TMD are also given. For passive TMD, the optimum results of the cases with st_max $=3$ and 4 were found as the same since the maximum $g_{1}$ value is 2.0755 which is not at the limit for both cases. This situation means that the stroke limitation for passive TMD is not a restriction if the st_max value is bigger than 2.0755 .

Table 3. The optimum results.

\begin{tabular}{lccccc}
\hline \multicolumn{1}{c}{ Parameter } & \multicolumn{2}{c}{ TMD } & \multicolumn{3}{c}{ ATMD } \\
\hline st_max & 2 & 3 and 4 & 2 & 3 & 4 \\
\hline $\mathrm{m}_{\mathrm{d}}(\mathrm{t})$ & 180 & 180 & 180 & 180 & 180 \\
$\mathrm{~T}_{\mathrm{atmd}}(\mathrm{s})$ & 0.9418 & 0.9434 & 0.8947 & 0.9941 & 1.0797 \\
$\xi_{\mathrm{d}}(\%)$ & 5.64 & 4.69 & 28.77 & 11.86 & 10.15 \\
$\mathrm{~K}_{\mathrm{p}}(\mathrm{Ns} / \mathrm{m})$ & - & - & -10000 & -1157.6 & 8762.9 \\
$\mathrm{~T}_{\mathrm{d}}(\mathrm{s})$ & - & - & 67.39 & 599.42 & -79.12 \\
$\mathrm{~T}_{\mathrm{i}}(\mathrm{s})$ & - & - & 8616 & -7687.9 & -2748.1 \\
$\mathrm{f}(\mathrm{x})(\mathrm{m})$ & 0.2820 & 0.2803 & 0.2469 & 0.1963 & 0.1898 \\
$\mathrm{~g}_{1}$ & 1.9999 & 2.0755 & 1.9999 & 2.9989 & 3.2983 \\
\hline
\end{tabular}

As given in the optimum results, the optimum mass of TMD and ATMD are at the maximum limit. It is a known issue and the proposed algorithm shows the efficiency by finding the mass at the upper bound. It is seen that optimum periods are decreasing, and optimum damping ratios are increasing by the reduction of stroke capacity value, st_max. The controller parameters show very different values with respect to cases of st_max, because all of these gain variables of PID controller formulation can use different sets of values to generate similar control signals in active control. When the design constraint $\left(g_{1}\right)$ values are inspected, it can be seen that passive TMD has a maximum value of 2.0755 instead of reaching the limit of st_max. ATMD needs more stroke capacity than TMD, and the maximum value is 3.2983 for the case with st_max $=4$. It is understood that the maximum stroke needed for TMD is that value.

The critical excitation considered for the objective function value is the BOL090 component of the Duzce (Turkey) record of the earthquake. Under this excitation, the maximum displacement of the upper story is $0.41 \mathrm{~m}$ for the uncontrolled structure. By using a TMD with a maximum mass of $5 \%$ of the superstructure, it is reduced to $0.2802 \mathrm{~m}$, while it is possible to reduce it down to $0.1897 \mathrm{~m}$. This situation can also be clearly seen from the time history plots of the critical excitation (Figure 5).

When the plots given for all st_max are inspected, it is clearly seen that TMD and ATMD are also effective in obtaining a quick steady state response, since vibrations are damped quickly. This is resulting from the optimum high damping values of ATMD cases. The optimum ATMD for all cases of st_max is also effective on all 44 excitations. The maximum top story responses are given for all excitations in Table 4 and the results are also plotted in Figure 6. 


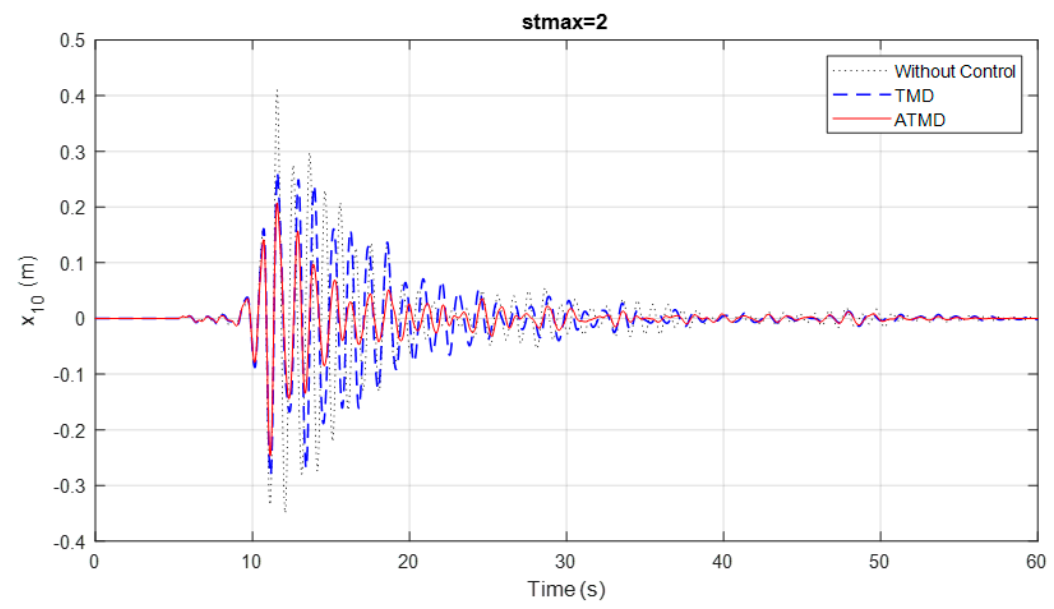

(a)

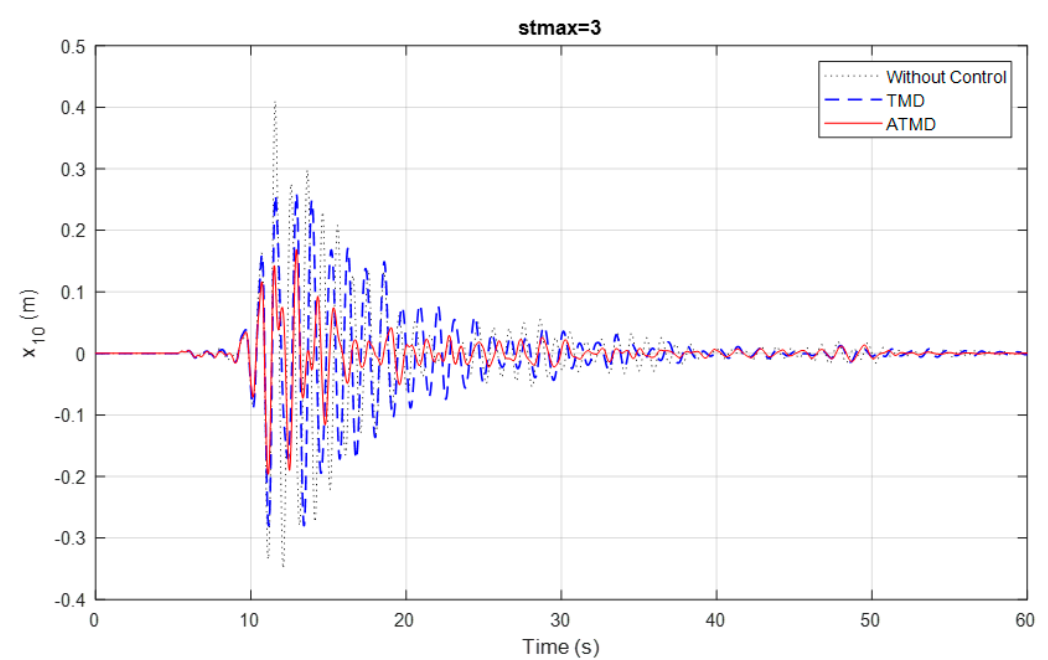

(b)

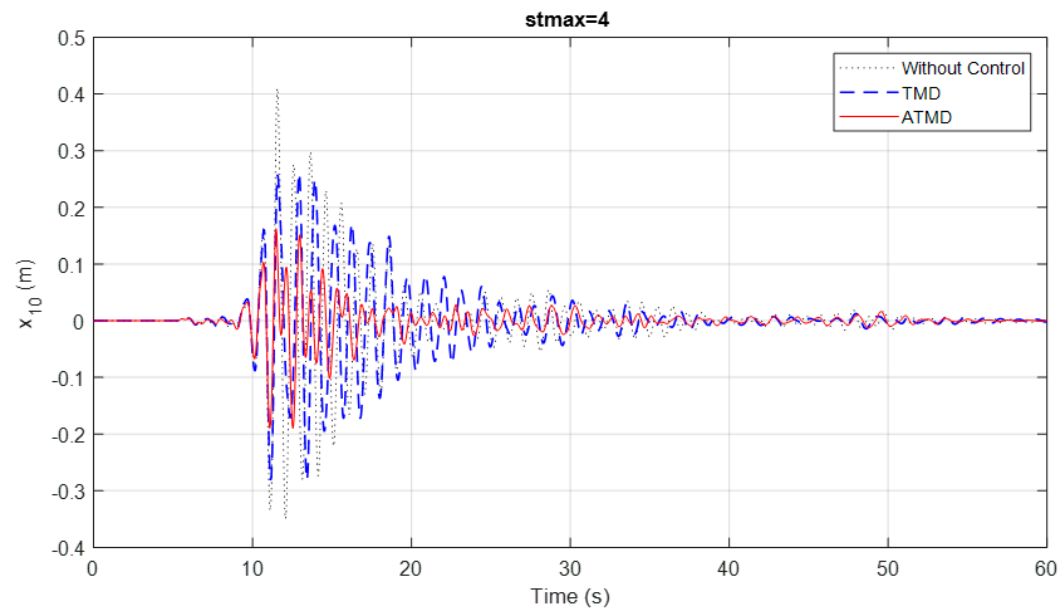

(c)

Figure 5. Time history displacement of the top story of the structure under the critical record. (a) st_max $=2$; (b) st_max $=3$; (c) st_max $=4$. 
Table 4. Maximum top story displacement for FEMA P-695 far-field ground motions.

\begin{tabular}{|c|c|c|c|c|c|c|c|}
\hline $\begin{array}{l}\text { Earthquake } \\
\text { Number }\end{array}$ & Component & $\begin{array}{l}\text { without } \\
\text { Control }\end{array}$ & $\begin{array}{c}\text { TMD } \\
\text { st_max }=2\end{array}$ & $\begin{array}{c}\text { TMD } \\
\text { st_max }= \\
3 \text { and } 4\end{array}$ & $\begin{array}{c}\text { ATMD } \\
\text { st_max }=2\end{array}$ & $\begin{array}{c}\text { ATMD } \\
\text { st_max }=3\end{array}$ & $\begin{array}{c}\text { ATMD } \\
\text { st_max }=4\end{array}$ \\
\hline \multirow{2}{*}{ Northridge } & NORTHR/MUL009 & 0.3693 & 0.2128 & 0.2221 & 0.2224 & 0.1628 & 0.1513 \\
\hline & NORTHR/MUL279 & 0.3110 & 0.2820 & 0.2802 & 0.2432 & 0.1766 & 0.1636 \\
\hline \multirow{2}{*}{ Northridge } & NORTHR/LOS000 & 0.1326 & 0.0942 & 0.0931 & 0.0974 & 0.1028 & 0.1090 \\
\hline & NORTHR/LOS270 & 0.2236 & 0.1487 & 0.1467 & 0.1337 & 0.1368 & 0.1434 \\
\hline \multirow{2}{*}{$\begin{array}{l}\text { Duzce, } \\
\text { Turkey }\end{array}$} & DUZCE/BOL000 & 0.2590 & 0.1721 & 0.1713 & 0.1416 & 0.1169 & 0.1186 \\
\hline & DUZCE/BOL090 & 0.4101 & 0.2820 & 0.2803 & 0.2469 & 0.1963 & 0.1898 \\
\hline \multirow{2}{*}{ Hector Mine } & HECTOR/HEC000 & 0.1118 & 0.1585 & 0.1641 & 0.1096 & 0.0938 & 0.0829 \\
\hline & HECTOR/HEC090 & 0.1317 & 0.1617 & 0.1667 & 0.1345 & 0.1314 & 0.1190 \\
\hline \multirow{2}{*}{$\begin{array}{c}\text { Imperial } \\
\text { Valley }\end{array}$} & IMPVALL/H-DLT262 & 0.1110 & 0.0665 & 0.0685 & 0.0493 & 0.0610 & 0.0727 \\
\hline & IMPVALL/H-DLT352 & 0.1894 & 0.1090 & 0.1124 & 0.0930 & 0.0986 & 0.0891 \\
\hline \multirow{2}{*}{$\begin{array}{l}\text { Imperial } \\
\text { Valley }\end{array}$} & IMPVALL/H-E11140 & 0.0765 & 0.0624 & 0.0616 & 0.0589 & 0.0600 & 0.0587 \\
\hline & IMPVALL/H-E11230 & 0.0705 & 0.1001 & 0.1015 & 0.0827 & 0.1032 & 0.1038 \\
\hline \multirow{2}{*}{ Kobe, Japan } & KOBE/NISO00 & 0.1112 & 0.1152 & 0.1164 & 0.0858 & 0.0819 & 0.0924 \\
\hline & KOBE/NIS090 & 0.1013 & 0.0951 & 0.0953 & 0.0826 & 0.1018 & 0.1006 \\
\hline \multirow{2}{*}{ Kobe, Japan } & KOBE/SHIOOO & 0.1045 & 0.1434 & 0.1445 & 0.1237 & 0.1199 & 0.1028 \\
\hline & KOBE/SHI090 & 0.0764 & 0.1009 & 0.1039 & 0.0758 & 0.0939 & 0.0973 \\
\hline \multirow{2}{*}{$\begin{array}{l}\text { Kocaeli, } \\
\text { Turkey }\end{array}$} & KOCAELI/DZC180 & 0.1547 & 0.1223 & 0.1213 & 0.1056 & 0.0871 & 0.0840 \\
\hline & KOCAELI/DZC270 & 0.2234 & 0.1972 & 0.1972 & 0.1772 & 0.1629 & 0.1441 \\
\hline \multirow{2}{*}{$\begin{array}{l}\text { Kocaeli, } \\
\text { Turkey }\end{array}$} & KOCAELI/ARC000 & 0.0407 & 0.0401 & 0.0408 & 0.0273 & 0.0269 & 0.0269 \\
\hline & KOCAELI/ARC090 & 0.0396 & 0.0341 & 0.0350 & 0.0306 & 0.0394 & 0.0417 \\
\hline \multirow{2}{*}{ Landers } & LANDERS/YER270 & 0.1797 & 0.1289 & 0.1284 & 0.1221 & 0.1274 & 0.1311 \\
\hline & LANDERS/YER360 & 0.1139 & 0.0828 & 0.0832 & 0.0763 & 0.0782 & 0.0792 \\
\hline \multirow{2}{*}{ Landers } & LANDERS/CLW-LN & 0.0834 & 0.0833 & 0.0848 & 0.0638 & 0.0638 & 0.0608 \\
\hline & LANDERS/CLW-TR & 0.1369 & 0.1498 & 0.1516 & 0.1296 & 0.1719 & 0.1733 \\
\hline \multirow{2}{*}{ Loma Prieta } & LOMAP/CAP000 & 0.1467 & 0.1673 & 0.1705 & 0.1446 & 0.1750 & 0.1599 \\
\hline & LOMAP/CAP090 & 0.0949 & 0.1065 & 0.1137 & 0.0934 & 0.1239 & 0.1288 \\
\hline \multirow{2}{*}{ Loma Prieta } & LOMAP/G03000 & 0.1139 & 0.0749 & 0.0749 & 0.0675 & 0.0666 & 0.0767 \\
\hline & LOMAP/G03090 & 0.1223 & 0.1394 & 0.1436 & 0.1163 & 0.1095 & 0.1078 \\
\hline \multirow{2}{*}{ Manjil, Iran } & MANJIL/ABBAR-L & 0.1236 & 0.0814 & 0.0810 & 0.0723 & 0.0929 & 0.1074 \\
\hline & MANJIL/ABBAR-T & 0.1847 & 0.1471 & 0.1474 & 0.1251 & 0.0969 & 0.1106 \\
\hline \multirow{2}{*}{$\begin{array}{c}\text { Superstition } \\
\text { Hills }\end{array}$} & SUPERST/B-ICC000 & 0.0848 & 0.1541 & 0.1561 & 0.1376 & 0.1448 & 0.1409 \\
\hline & SUPERST/B-ICC090 & 0.0837 & 0.0959 & 0.0974 & 0.0797 & 0.0859 & 0.0838 \\
\hline \multirow{2}{*}{$\begin{array}{c}\text { Superstition } \\
\text { Hills }\end{array}$} & SUPERST/B-POE270 & 0.1151 & 0.1291 & 0.1325 & 0.0787 & 0.0816 & 0.0808 \\
\hline & SUPERST/B-POE360 & 0.1374 & 0.1269 & 0.1321 & 0.0820 & 0.0787 & 0.0706 \\
\hline \multirow{2}{*}{$\begin{array}{c}\text { Cape } \\
\text { Mendocino }\end{array}$} & CAPEMEND/RIO270 & 0.1829 & 0.1540 & 0.1533 & 0.1353 & 0.1267 & 0.1250 \\
\hline & CAPEMEND/RIO360 & 0.1398 & 0.1173 & 0.1166 & 0.0981 & 0.0838 & 0.0822 \\
\hline \multirow{2}{*}{$\begin{array}{l}\text { Chi-Chi, } \\
\text { Taiwan }\end{array}$} & CHICHI/CHY101-E & 0.1608 & 0.1079 & 0.1121 & 0.0875 & 0.0950 & 0.0995 \\
\hline & CHICHI/CHY101-N & 0.3546 & 0.2080 & 0.2055 & 0.1834 & 0.1410 & 0.1502 \\
\hline \multirow{2}{*}{$\begin{array}{l}\text { Chi-Chi, } \\
\text { Taiwan }\end{array}$} & CHICHI/TCU045-E & 0.1085 & 0.0836 & 0.0845 & 0.0661 & 0.0833 & 0.0855 \\
\hline & CHICHI/TCU045-N & 0.1514 & 0.1238 & 0.1228 & 0.1109 & 0.1061 & 0.1091 \\
\hline \multirow{2}{*}{ San Fernando } & SFERN/PEL090 & 0.0851 & 0.0823 & 0.0844 & 0.0602 & 0.0657 & 0.0792 \\
\hline & SFERN/PEL180 & 0.0614 & 0.0349 & 0.0360 & 0.0279 & 0.0266 & 0.0280 \\
\hline \multirow{2}{*}{ Friuli, Italy } & FRIULI/A-TMZ000 & 0.0847 & 0.0614 & 0.0608 & 0.0524 & 0.0513 & 0.0582 \\
\hline & FRIULI/A-TMZ270 & 0.1013 & 0.0851 & 0.0847 & 0.0722 & 0.0868 & 0.0825 \\
\hline Maximum & & 0.4101 & 0.2820 & 0.2803 & 0.2469 & 0.1963 & 0.1898 \\
\hline Average & & 0.1455 & 0.1233 & 0.1246 & 0.1047 & 0.1027 & 0.1023 \\
\hline
\end{tabular}




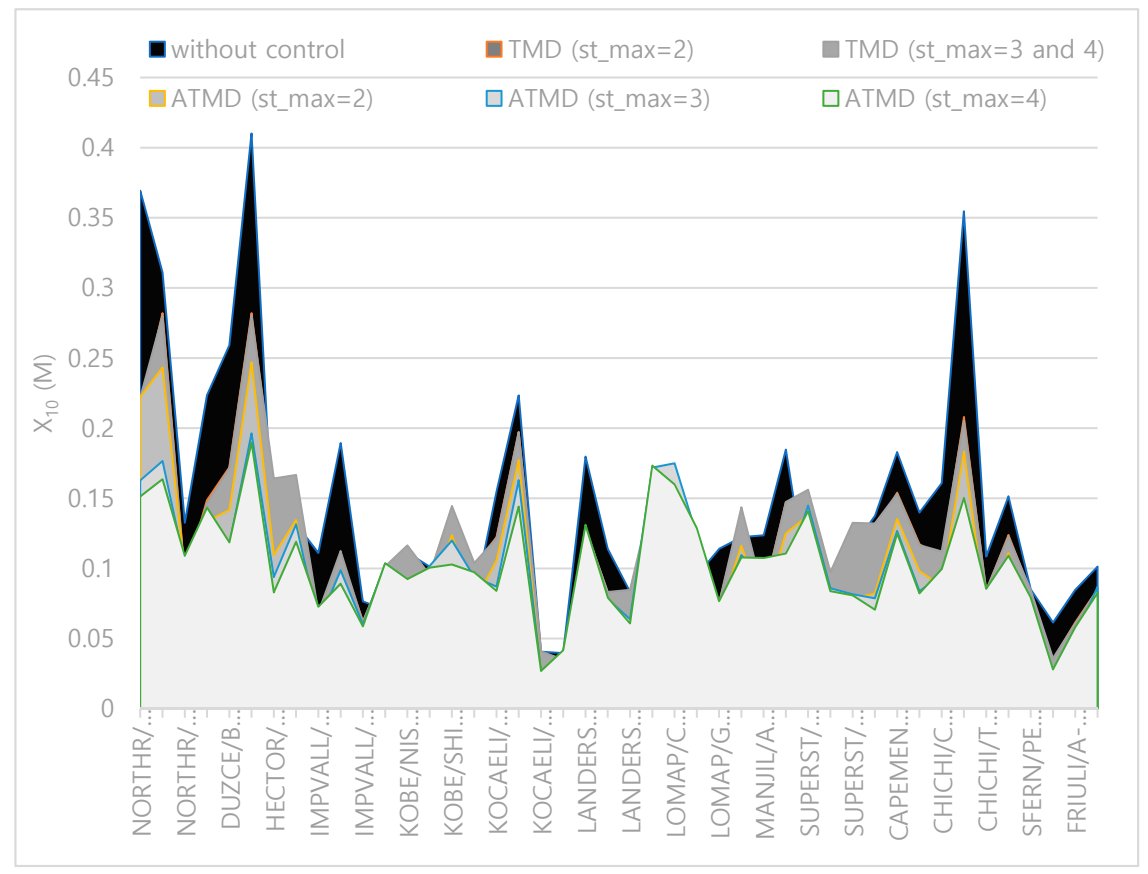

Figure 6. Maximum top story displacement plot for FEMA P-695 far-field ground motions.

\section{Conclusions}

The metaheuristic algorithm called harmony search is successfully modified to optimize the physical parameters of a mass damper and the controller gains of PID controller, which generates a control signal to produce an active control force.

Based on the results, it is clearly seen that ATMD is both effective in the reduction of displacements under critical excitation and the other excitations considered in the optimization process. In the structure case tested for the method, it is possible to reduce maximum top story displacement by $39.78 \%$ for the most limited case of the stroke of ATMD, while TMD is effective by $31.22 \%$. By the increase in the stroke capacity, TMD is not effective to show a better reduction performance, but ATMD can reduce displacements up to $53.71 \%$. The reduction percentages are plotted for TMD and ATMD for different st_max values in Figure 7.

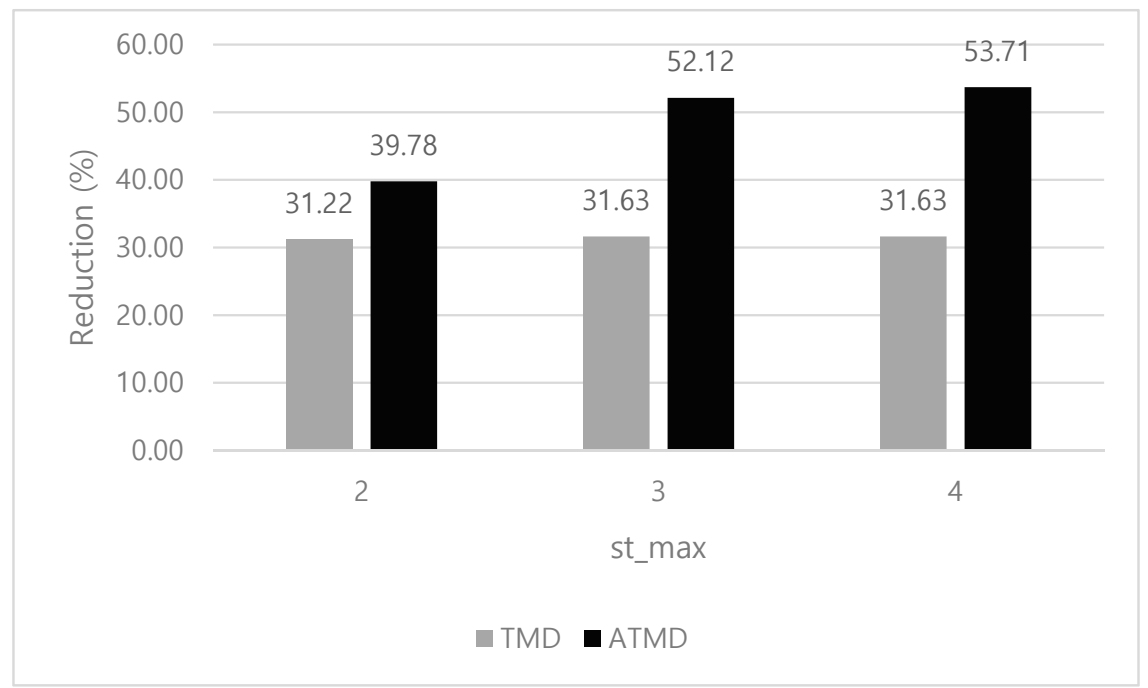

Figure 7. The reduction percentages for TMD and ATMD for st_max cases. 
In order to provide the optimum control, the amount of the need maximum control force is $16.23 \%$, $38.32 \%$ and $41.12 \%$ of the total weight of the structure for st_max $=2$, st_max $=3$ and st_max $=4$ cases, respectively. By the increase of the stroke limitation, the extreme increase of the control forces may also increase the cost of application due to the required actuator.

Another disadvantage of the usage of high stroke capacity for ATMD is the increase of the maximum accelerations. For the critical excitation, it is possible to reduce the maximum acceleration by $23 \%$ for the stroke capacity limited by 2 , while ATMD with higher strokes increase it by $23 \%$ and $29 \%$. In these cases, and if non-constructive components such as machine, equipment, shelfs, statues etc. need to be protected, additional use of base isolators is recommended. Passive TMD has an advantage on accelerations with $32 \%$ compared to uncontrolled structure.

As the final remark related to the final technical issue about structural control, the decision to use TMD and ATMD can be made by trying the structural case, since both systems have advantages and disadvantages.

For high stroke capacity limitations, optimum ATMD is very effective in the reduction in structural displacements, but these cases may have a high cost for the constructer or designer of ATMD system. The optimum TMD cases have less reduction capacity than ATMD for structural displacements, while the constraint about stroke limitation cannot gain bigger values than 2.0755 for the cases with maximum 3 and 4 permitted. This situation proves that usage of TMD may be a feasible way in cost, but ATMD can reduce the displacements if the demanded stroke can be physically provided by considering the rapid increase in the cost of the system.

For different runs of the optimization methodology, it is possible to find different optimum design variables. This situation is generally seen for PID controller gain. The different sets of PID controller parameters can be effective in generating similar control forces. Hence, the objective function value of all optimum sets is be equal to each other.

Modifying the HS algorithm with the use of the current best solution with a possibility called BSCR helps solve the complex vibration problem including the random vibration behavior of seismic excitations. The trapping to a local optimum solution was prevented by using a $30 \%$ possibility of using the best current solution. The PID-controlled ATMD, which is optimized according to time-domain analysis with the employment of the modified HS, is an effective and feasible approach for ATMD controlled seismic structures.

In the future studies, different objectives and various design constraints can be also considered in the optimization methodology of tuning of ATMD. Parametric structural cases and multiple cases of structures also need to be conducted for global conclusions about optimum design.

Author Contributions: A.E.K. was in the control of all sessions, since the study is a part of her PhD thesis. A.E.K., G.B., and S.M.N. generated the analysis code. A.E.K. and S.M.N. developed theory background and formulations of the active control system. The modification of HS was done by A.E.K. and G.B. The text of the paper was composed by S.M.N., G.B., and A.E.K. The figures were drawn by S.M.N., G.B., and A.E.K., Z.W.G. supervised the research direction. All authors have read and approved the final manuscript.

Funding: This work was supported by the National Research Foundation of Korea (NRF) grant funded by the Korea government (MSIT) (2020R1A2C1A01011131). This research was also supported by the Energy Cloud R\&D Program through the National Research Foundation of Korea (NRF) funded by the Ministry of Science, ICT (2019M3F2A1073164).

Conflicts of Interest: The authors declare no conflict of interest.

\section{References}

1. Miyamoto, H.K.; Gilani, A.S.J.; Gündoğdu, Y.Z. Innovative Seismic Retrofit of An Iconic Building. In Proceedings of the 7th National Conference on Earthquake Engineering, Istanbul, Turkey, 30 May-3 June 2011.

2. Soto, M.G.; Adeli, H. Tuned mass dampers. Arch. Comput. Methods Eng. 2013, 20, 419-431. [CrossRef]

3. Bekdaş, G.; Nigdeli, S.M. Estimating optimum parameters of tuned mass dampers using harmony search. Eng. Struct. 2011, 33, 2716-2723. [CrossRef] 
4. Ankireddi, S.Y.; Yang, H.T. Simple ATMD control methodology for tall buildings subject to wind loads. J. Struct. Eng. 1996, 122, 83-91. [CrossRef]

5. Mackriell, L.E.; Kwok, K.C.S.; Samali, B. Critical mode control of a wind-loaded tall building using an active tuned mass damper. Eng. Struct. 1997, 19, 834-842. [CrossRef]

6. Yan, N.; Wang, C.M.; Balendra, T. Optimal damper characteristics of ATMD for buildings under wind loads. J. Struct. Eng. 1999, 125, 1376-1383. [CrossRef]

7. Qu, Z.Q.; Shi, Y.; Hua, H. A reduced-order modeling technique for tall buildings with active tuned mass damper. Earthq. Eng. Struct. Dyn. 2001, 30, 349-362. [CrossRef]

8. Samali, B.; Al-Dawod, M. Performance of a five-storey benchmark model using an active tuned mass damper and a fuzzy controller. Eng. Struct. 2003, 25, 1597-1610. [CrossRef]

9. Samali, B.; Al-Dawod, M.; Kwok, K.C.; Naghdy, F. Active control of cross wind response of 76-story tall building using a fuzzy controller. J. Eng. Mech. 2004, 130, 492-498. [CrossRef]

10. Li, C. Evaluation of the lever-type active tuned mass damper for structures. Struct. Control Health Monit. 2004, 11, 259-271. [CrossRef]

11. Han, B.; Li, C. Seismic response of controlled structures with active multiple tuned mass dampers. Earthq. Eng. Eng. Vib. 2006, 5, 205-213. [CrossRef]

12. Pourzeynali, S.; Lavasani, H.H.; Modarayi, A.H. Active control of high rise building structures using fuzzy logic and genetic algorithms. Eng. Struct. 2007, 29, 346-357. [CrossRef]

13. Li, C.; Xiong, X. Estimation of active multiple tuned mass dampers for asymmetric structures. Struct. Eng. Mech. 2008, 29, 505-530. [CrossRef]

14. Guclu, R.; Yazici, H. Vibration control of a structure with ATMD against earthquake using fuzzy logic controllers. J. Sound Vib. 2008, 318, 36-49. [CrossRef]

15. Guclu, R.; Yazici, H. Seismic-vibration mitigation of a nonlinear structural system with an ATMD through a fuzzy PID controller. Nonlinear Dyn. 2009, 58, 553. [CrossRef]

16. Guclu, R.; Yazici, H. Self-tuning fuzzy logic control of a non-linear structural system with ATMD against earthquake. Nonlinear Dyn. 2009, 56, 199. [CrossRef]

17. Li, C.; Li, J.; Qu, Y. An optimum design methodology of active tuned mass damper for asymmetric structures. Mech. Syst. Signal Process. 2010, 24, 746-765. [CrossRef]

18. Li, C. Effectiveness of active multiple-tuned mass dampers for asymmetric structures considering soil-structure interaction effects. Struct. Des. Tall Spec. Build. 2012, 21, 543-565. [CrossRef]

19. Fitzgerald, B.; Basu, B. Active tuned mass damper control of wind turbine nacelle/tower vibrations with damaged foundations. Key Eng. Mater. Trans. Tech. Publ. 2013, 569, 660-667. [CrossRef]

20. Amini, F.; Hazaveh, N.K.; Rad, A.A. Wavelet PSO-based LQR algorithm for optimal structural control using active tuned mass dampers. Comput.-Aided Civil Infrastruct. Eng. 2013, 28, 542-557. [CrossRef]

21. You, K.P.; You, J.Y.; Kim, Y.M. LQG control of along-wind response of a tall building with an ATMD. Math. Probl. Eng. 2014. [CrossRef]

22. Ayorinde, E.O.; Warburton, G.B. Minimizing structural vibrations with absorbers. Earthq. Eng. Struct. Dyn. 1980, 8, 219-236. [CrossRef]

23. Shariatmadar, H.; Golnargesi, S.; Akbarzadeh Totonchi, M.R. Vibration control of buildings using ATMD against earthquake excitations through interval type-2 fuzzy logic controller. Asian J. Civil Eng.-Build. Hous. 2014, 15, 321-338.

24. Lu, X.; Li, P.; Guo, X.; Shi, W.; Liu, J. Vibration control using ATMD and site measurements on the Shanghai World Financial Center Tower. Struct. Des. Tall Spec. Build. 2014, 23, 105-123. [CrossRef]

25. Shariatmadar, H.; Meshkat Razavi, H. Seismic control response of structures using an ATMD with fuzzy logic controller and PSO method. Struct. Eng. Mech. 2014, 51, 547-564. [CrossRef]

26. Soleymani, M.; Khodadadi, M. Adaptive fuzzy controller for active tuned mass damper of a benchmark tall building subjected to seismic and wind loads. Struct. Des. Tall Spec. Build. 2014, 23, 781-800. [CrossRef]

27. Li, C.; Cao, B. Hybrid active tuned mass dampers for structures under the ground acceleration. Struct. Control Health Monit. 2015, 22, 757-777. [CrossRef]

28. Cao, L.; Li, C. Enhanced hybrid active tuned mass dampers for structures. Struct. Control Health Monit. 2018, 25, e2067. [CrossRef]

29. Heidari, A.H.; Etedali, S.; Javaheri-Tafti, M.R. A hybrid LQR-PID control design for seismic control of buildings equipped with ATMD. Front. Struct. Civ. Eng. 2018, 12, 44-57. [CrossRef] 
30. MATLAB, version 7.10.0 (R2010a); The MathWorks Inc: Natick, MA, USA, 2010.

31. De Domenico, D.; Ricciardi, G.; Takewaki, I. Design strategies of viscous dampers for seismic protection of building structures: A review. Soil Dyn. Earthq. Eng. 2019, 118, 144-165. [CrossRef]

32. Greco, R.; Marano, G.C. Optimum design of tuned mass dampers by displacement and energy perspectives. Soil Dyn. Earthq. Eng. 2013, 49, 243-253. [CrossRef]

33. De Domenico, D.; Ricciardi, G. Earthquake-resilient design of base isolated buildings with TMD at basement: Application to a case study. Soil Dyn. Earthq. Eng. 2018, 113, 503-521. [CrossRef]

34. Lavan, O.; Dargush, G.F. Multi-objective evolutionary seismic design with passive energy dissipation systems. J. Earthq. Eng. 2009, 13, 758-790. [CrossRef]

35. Geem, Z.W.; Kim, J.H.; Loganathan, G.V. A new heuristic optimization algorithm: Harmony search. Simulation 2001, 76, 60-68. [CrossRef]

36. Singh, M.P.; Singh, S.; Moreschi, L.M. Tuned mass dampers for response control of torsional buildings. Earthq. Eng. Struct. D 2002, 31, 749-769. [CrossRef]

37. Quantification of Building Seismic Performance Factors; Technical Report No. FEMA P-695; FEMA: Washington, DC, USA, 2009.

38. Tributsch, A.; Adam, C. Evaluation and analytical approximation of Tuned Mass Damper performance in an earthquake environment. Smart Struct. Syst. 2012, 10, 155-179. [CrossRef]

39. De Domenico, D.; Ricciardi, G. Earthquake protection of structures with nonlinear viscous dampers optimized through an energy-based stochastic approach. Eng. Struct. 2019, 179, 523-539. [CrossRef]

40. Di Matteo, A.; Furtmüller, T.; Adam, C.; Pirrotta, A. Optimal design of tuned liquid column dampers for seismic response control of base-isolated structures. Acta Mech. 2018, 229, 437-454. [CrossRef]

41. De Domenico, D.; Ricciardi, G.; Zhang, R. Optimal design and seismic performance of tuned fluid inerter applied to structures with friction pendulum isolators. Soil Dyn. Earthq. Eng. 2020, 132, 106099. [CrossRef]

(C) 2020 by the authors. Licensee MDPI, Basel, Switzerland. This article is an open access article distributed under the terms and conditions of the Creative Commons Attribution (CC BY) license (http://creativecommons.org/licenses/by/4.0/). 